\title{
A Comparative Study of Public and Private Senior Secondary School Students' Science Achievement in Katsina State, Nigeria
}

\author{
Dr Olasehinde, Kayode John \\ Department of Science Education, Faculty of Science and Education, \\ Federal University, Dutsin-Ma, Katsina State \\ kayode_olasehinde@yahoo.com, kolasehinde@fudutsinma.edu.ng \\ Dr Olatoye, Rafiu Ademola \\ Department of Science Education, Faculty of Science and Education, \\ Federal University, Dutsin-Ma, Katsina State \\ kingdemola@yahoo.com, rolatoye@fudutsinma.edu.ng
}

\section{Doi:10.5901/jesr.2014.v4n3p203}

\section{Abstract}

This study compared senior secondary school students' science achievement in public and private schools in Katsina State, Nigeria. The descriptive survey research was employed to carry out the study. Two hundred and four students (204) senior secondary school students were randomly selected for the study. One instrument, Science Achievement Test (SAT) was used to collect data for the study. Data were analysed using t-test statistic. The results showed that there is a significant difference between public and private secondary school students' science achievement $(t=-3.537, p<0.05)$. Private schools students performed significantly better than their public school counterparts $(t=-3.537, p<0.05)$. There is no significant difference between public and private senior secondary school students' achievement in biology and chemistry $(t=-2.789$ and $-1.149, p>$ 0.05 respectively); there is a significant difference in physics achievement between public and private school students ( $t=$ $3.158, p<0.05)$ and there is no significant difference between male and female students in science achievement in public and private schools ( $t=-0.124$ and $-0.158, p<0.05$ respectively). It was recommended among others that more supervisory roles be played on public schools teachers to make them work better on their science students.

Keywords: Public, private, secondary school students, science achievement

\section{Introduction}

Science Education is designed to guide the world towards a scientifically literate society. It is important for an understanding of science as it offers personal fulfilments and excitements. The world is confronted daily with issues that require scientific way of thinking for informed discussion, management and sharing of resources such as air, water and vegetation (Ellis, 2010).

The World Summit on Sustainable Development (WSSD) (2002), as reported in Akporehwe and Onwiodukit (2013) affirmed the role of Science and Technology Education as an enabler for sustainable development. Nigerian Government in acknowledging the strategic role science holds for national development has directed University as a matter of policy to admit candidates on a ratio of 60:40 in favour of science courses.

The major index used for assessing scientific advancement through education is the performance of the students. Obemeata (1995) asserted that the achievement of technological development through education depends largely on the performance of secondary school students in science and mathematics. Olatoye (2002) opined that science education lays foundation for work in science-related fields by acquainting learners with certain knowledge skills and attitudes. Ogbonna (2007) observed that there has been a world-wide recognition of science and thereby science education has found a central place in the curricula of school at all levels.

Public and private schools are institutions owned as the names denote. The public school in Nigeria have Federal State, and Local Governments as their proprietors while the private schools have individuals, associations or organisations as the owners. Berkeley Parent Network (2009) asserted that private schools vary widely and level of parental involvement varies from one private school to the other. What is important for a parent is to choose private school that has characteristics that match what they are looking for as a family. Parents pay for the cost of educating 
their children in private schools and therefore tend to be more involved in dictating what the schools offer than parents whose children are attending public schools (Olatoye and Agbatogun, 2009).

Table1: Characteristics of Private and Public Schools

\begin{tabular}{|l|l|}
\hline Private School & Public School \\
\hline Mostly have small class size & Mostly have big class size \\
\hline Lack accountability to the public & Accountable to the public \\
\hline It is autonomous & It is not autonomous \\
\hline Ignore recent curricular trends in education & Do not ignore curricular trends in education \\
\hline Do not always hire certified teachers & Hire certified teachers \\
\hline Most have religion inclinations & Do not have religious inclinations \\
\hline Set no fund apart for teacher professional development & Set fund apart for teacher professional development \\
\hline Set attraction to parents to show safe, neat and welcoming environment & Set no attraction beyond Government provision \\
\hline Do not use up- to- date teaching methods & Use up to date teaching methods \\
\hline
\end{tabular}

Source: Lubienski, Lubienski and Crane (2009).

Despite the characteristics listed in table 1, scholars are contesting the superiority of the schools in term of achievement in science. Lubienski, Lubienski, and Crane, (2009) said after holding demographic factors constant, public schools performed just as well if not better than private schools. It is important to say that the characteristics listed in the table 1 may not be completely applicable to the various school types in some countries as education policy may differ. Olatoye and Agbatogun (2009) reported that there exists a significant difference in mathematics and science achievement of public and private school pupils in which private school pupils performed better than public school counterparts in mathematics and science. The discussions so far show that there is a need to compare private and public school students in science achievement.

This study therefore sought to compare senior secondary school students' science achievement in public and private schools in Katsina State, Nigeria.

\section{Research Questions}

The following research questions are answered in this study:

1. Is there any significant difference between public and private school students' achievement in science?

2. Is there any significant difference between public and private school students' achievement in (i) Biology (ii) Chemistry (iii) Physics?

3. Is there any significant difference between male and female students' achievement in public schools?

4. Is there any significant difference between male and female students' achievement in private schools?

\section{Methodology}

\subsection{Research Design}

The descriptive survey research design was employed to carry out this study. The aim of the researchers was to record, analyze and interpret the existing conditions or variables. The research is non-experimental and therefore variables were not manipulated. This makes descriptive survey research design suitable for this study. This design also accommodates generalization of findings of the study upon the target population from which only a representative sample was actually studied.

\subsection{Target Population and Sample}

The target population for the study comprised all the students in Senior Secondary School (SSS) Two in Katsina State, Nigeria. Katsina State is one of the 36 states in Nigeria. It has cultural and educational similarities with the other six states in the North-West geo-political zone of Nigeria. Katsina state was divided into 3 zones namely: Daura, Funtua and Katsina. This is the existing political divisions in the state. A random sample of one Local Government Area (LGA) was 
selected from each zone. From each Local Government Area, a random sample of two public and two private schools were selected from each LGA and a total of 12 schools ( 6 public and 6 private schools) were selected from the entire state. From each school, twenty SSS 2 Science Students were randomly selected to participate in the study. Thus a total of 240 students participated in the study. The average age of the students is 17 years.

\subsection{Instrumentation}

One instrument was used to collect data for this study; Science Achievement Test (SAT). SAT is a 30-item achievement test that covers the three core subjects in science namely biology, chemistry and physics. Ten items were drawn from each of these subject areas. Respondents were asked to indicate their gender and type of school on the achievement test.

Examples of items on SAT:

1. A group of closely related organisms capable of interbreeding to produce fertile offspring are known as members of (a) kingdom (b) class (c) family (d) species

2. How many orbital is in the d-sub shell? (a) 1 (b) 3 (c) 5 (d) 7 .

3. The derived unit of pressure can be expressed as: (a) $\mathrm{Kgms}^{-2}$ (b) $\mathrm{Kgm}^{-} \mathrm{s}^{-2}$ (c) $\mathrm{Kgm}^{-2} \mathrm{~s}^{-2}$ (d) $\mathrm{Kgm}^{-1} \mathrm{~s}^{2}$

The content validity of the achievement tests was ensured through experts' suggestions and guidance. Experts in test construction helped in critiquing the items. All the achievement items were selected from already standardised items produced by the West African Examinations Council. The items selected were only on the topics covered in all the schools selected for the study. The test retest reliability co-efficient for SAT was 0.849 .

\subsection{Method of Data Analysis}

The data collected were analysed using Statistical Package for Social Sciences (SPSS) version 17.0. All the research questions were answered using t-test.

\section{Results}

4.1 Research Question1: Is there any significant difference between public and private school students' achievement in science?

Table 2: Comparison of Public and Private Schools in Science Achievement

\begin{tabular}{|c|c|c|c|c|c|c|c|c|c|}
\hline Variable & School Type & $\mathrm{N}$ & Mean & Std Dev & Std Err Mean & df & T & P & Remark \\
\hline \multirow{2}{*}{ Science Achievement } & Public & 120 & 6.5750 & 2.73681 & .24984 & \multirow{2}{*}{202} & -3.537 & \multirow{2}{*}{0.001} & $*$ \\
& Private & 84 & 8.1190 & 3.48976 & .38076 & & & \\
\hline
\end{tabular}

* Significant $(p>0.05)$.

In table 2 there is a significant difference between public and private secondary school students' achievement in science $(\mathrm{t}=-3.537, \mathrm{p}<0.05)$. The mean achievement for public school students is 6.575 while that of private school is 8.119 . Though students' achievements in both public and private schools are below average (the maximum obtainable score is 30), however, private school students performed significantly better than their public school counterparts.

4.2 Research Question 2: Is there any significant difference between public and private school students' achievement in (i) Biology (ii) Chemistry (iii) Physics?

Table 3: Comparison of Public and Private school students' achievement in Biology, Chemistry and Physics achievemen

\begin{tabular}{|l|l|c|c|c|c|c|c|c|c|}
\hline Variables & School Type & $\mathrm{N}$ & Mean & Std Dev & Std Err Mean & $\mathrm{df}$ & $\mathrm{T}$ & $\mathrm{p}$ & Remark \\
\hline \multirow{2}{*}{ Biology Achievement } & Public & 120 & 2.2917 & 1.45172 & .13252 & \multirow{2}{*}{202} & -2.789 & \multirow{2}{*}{.006} & \multirow{2}{*}{ NS } \\
& Private & 84 & 2.9167 & 1.73697 & 18952 & & & & \multirow{2}{*}{ NS } \\
\hline \multirow{2}{*}{ Chemistry Achievement } & Public & 120 & 2.2083 & 1.44882 & .13226 & \multirow{2}{*}{202} & -1.149 & \multirow{2}{*}{.252} & \multirow{2}{*}{ N } \\
& Private & 84 & 2.4524 & 1.55544 & .16971 & & & \\
\hline \multirow{2}{*}{ Physics Achievement } & Public & 120 & 2.0750 & 1.40923 & .12864 & \multirow{2}{*}{202} & -3.158 & \multirow{2}{*}{.002} & \multirow{2}{*}{ * } \\
& Private & 84 & 2.7500 & 1.62714 & .17754 & 2 & & & \\
\hline
\end{tabular}

*Significant $(p<0.05)$ NS= Not significant $(p>0.05)$ 
Table 3 reveals that there is no significant difference between public and private students' achievement in Biology and Chemistry ( $\mathrm{t}=-2.789$ and $-1.149, \mathrm{p}>0.05$ respectively). However, there is a significant difference between public and private school students' achievement in Physics $(t=-3.158, p<0.05)$. Private school students performed better in Physics than their public school counterparts. It is worthy to note that the performance is poor in both public and private schools. Public school students had an average of 2.08 out of the maximum obtainable score of 10 in physics while private school students had 2.75. Also the mean achievement score in the biology and chemistry achievements are equally poor.

\subsection{Research Question3: Is there any significant difference between male and female students' science achievement in private schools?}

Table 4: Comparison of Male and Female Students' Science Achievement in Private Schools

\begin{tabular}{|l|l|c|c|c|c|c|c|c|c|}
\hline Variable & Gender & $\mathrm{N}$ & Mean & Std Dev & Std Err & df & T & P & Remark \\
\hline \multirow{2}{*}{ Science Achievement } & Male & 42 & 8.0714 & 3.40296 & .52509 & 82 & -0.124 & .901 & NS \\
& Female & 42 & 8.61512 & 3.61512 & .55783 & 82 & & \\
\hline
\end{tabular}

NS= Not Significant $(p>0.05)$.

Table 4 shows that there is no significant difference between male and female students in science achievement in private schools $(t=-0.124, p>0.05)$. Analysis in table 3 was only done for students in private schools only. This enables us to know whether gender difference in science achievement could exist in different school types (public and private schools).

\subsection{Research Question 4: Is there any significant difference between male and female students in science achievement in public schools?}

Table 5: Comparison of Male and Female Students in Science Achievement in Public Schools

\begin{tabular}{|l|l|l|l|l|c|c|c|c|c|}
\hline Variable & Gender & $\mathrm{N}$ & Mean & Std Dev & Std Err Mean & $\mathrm{df}$ & $\mathrm{T}$ & $\mathrm{P}$ & Remark \\
\hline \multirow{2}{*}{ Science Achievement } & Male & 77 & 6.5455 & 2.71713 & .30965 & \multirow{2}{*}{118} & \multirow{2}{*}{0.158} & \multirow{2}{*}{.875} & \multirow{2}{*}{ NS } \\
& Female & 43 & 6.6279 & 2.80326 & .42749 & & & & \\
\hline
\end{tabular}

NS= Not Significant $(p>0.05)$.

Table 5 shows that there is no significant difference between male and female students' science achievement in public schools $(t=-0.158, p>0.05)$. Research question 4 looks at gender differences in science achievement in public schools only. The female students mean score in science achievement is 6.63 as against that of males which is 6.56 . This shows that despite the 'no significant difference' revealed in table 5 female students slightly performed better than the male students in public schools. The fact is that the slight difference in achievement is not statistically significant.

\section{Discussion}

The findings reveal that the there is a significant difference between public and private school students in science achievement $(t=-3.537, p<0.05)$. The findings show significant difference between the mean scores of the private school students' achievement in science. The mean score for the private school students is 8.12 while the public school students' mean science achievement score is 6.58 . This shows that the private school students are better than the public school students in science achievement. Factors that could cause this include small class size, safe, neat and welcoming environment in private schools. Also the teachers devote more time for the teaching of the students. This is contrary to the poor attitude to teaching of the teachers in public schools.

Furthermore, the results show that there is no significant difference between the public and private school students' achievement in biology and chemistry ( $t=-2.789$ and $-1.149, p>0.05$ respectively). In physics however, there is a significant difference $(t=-3.158, p<0.05)$. The mean scores of public and private school students in biology, chemistry and physics range from 2.0750 to 2.9167 . The obtainable mean score is 10 . The obtained mean score in each subject is far lower than average of 5 . It can therefore be generalised that the performance is not good. It shows that science achievement is poor regardless of the school type (public or private).

Tables 4 and 5 reveal that there is no significant difference between male and female students' science achievement in public and private schools $(t=-0.124$, and $-0.158, p>0.05$ respectively). However Olatoye and Agbatogun 
(2009), Olatoye (2009a, 2009b) reported that there is a significant difference between public and private school students' achievement in science. It is evident that gender factor has no influence on the performance of the students. It is important to note that both public and private school female students have higher mean scores. This is contrary to the popular opinion among researchers that the male students are better than the female students in science achievement.

Olatoye (2002) opined that science education lays foundation for work in science-related fields by acquainting learners with certain knowledge and skills. With the very low achievement of students in science reported in the study, there is need to unravel the reasons for such poor results. According to Olatoye (2009a, 2009b) factors such as test anxiety, motivation for examinations, study habit, self-concept have significant influence on students' achievement in science.

\section{Conclusion}

This study has been able to establish the fact that private school students in Katsina State are better in science achievement than their counterparts in the public schools. Private school students are especially better in physics. These findings tend to provide justification for parents who have found private schools as an alternative to government-owned public schools. It is however important to stress that students' mean achievement scores in both public and private schools are below average. This shows that a lot of work still needs to be done to raise students' achievement in both public and private schools. The no significant difference in achievement by gender is an assurance that there is hope that male and female students have the potential of benefiting from science teaching.

\section{Recommendations}

It is therefore recommended that government at all levels should support the running of both public and private schools. More supervision should be done on the public schools to make teachers work better on the students in science. Retraining of the teachers in both school types to improve their science instructional strategies should be the concern of the all education stake-holders.

\section{References}

Agbatogun, A. O. (2009). School Factors as Predictors of Junior Secondary School Students Attitude Towards Social Studies. An Unpublished M.Ed Dissertation, Institute of Education, Olabisi Onabanjo University, Ago Iwoye.

Akporehwe, J.N. \& Onwioduokit F.A. (2013). Enhancing Scientific Attitude through Activity-Based Approaches. Academia.edu Retrieved 24th June,2013 http://www.academiai.edu/719335/Enhanching_Scientific_attitude_Activity_Based_Approaches

Berkely Parent Network (2009). Parents' Involvement in Private Schools. Retrieved 22nd July, 2013. http://parentberkelyedu /recommended/schools/parentinvolve.html.

Ellis, J. D. (2010). The Influence of the National Science Education Standards on Science Curriculum, University of Kansas. In: Wikipedia Free Encyclopaedia, National Science Education Standards http://en.wikipeadia.org/w/index.php ?titlenational_science_education_standardsaction=edit\&section

Lubienski, S., Lubienski, C. and Crane, C. (2009). 'Public Schools Outperformed Private Schools in Mathemathics', Publication of College of Education, Illinois University, USA. Retrieved online 13 April, 2013

Obemeata, J. O. (1995). Education: An Unprofitable Industry in Nigeria. Post graduate School Interdisciplinary Research Discourse. University of Ibadan, Ibadan, Nigeria.

Ogbonna, F. N. (2007). Influence of Parental Involvement and Self -Concept on Science Achievement of Junior Secondary School Students in Ogun State, Nigeria. A Pre-field Research Proposal Presented at Research Seminar of the Institute of Education. Olabisi Onabanjo University, Ago Iwoye.

Olatoye, R A. \& Agbatogun A. A. (2009). Parental involvement as correlates of pupils' achievement in mathematics and science in Ogun state, Nigeria. Educational Research and Review, 14 (10), 457-464.

Olatoye, R A. (2009a). Study habit, Self-concept and Science Achievement of Public and Private Junior Secondary School Students in Ogun State, Nigeria. African Research Review, I3, (4 ), 492-506

Olatoye, R. A. (2009b) Students' Test Anxiety. Motivation for examinations and science achievement in junior secondary schools in ogun state, Nigeria. International Journal of Psychology and Counselling,1 (10), 194-198.

Olatoye, R.A, (2002). A Causal Model of School Factors as Determinants of Science Achievement in Lagos State Secondary Schools. An Unpublished PhD Thesis, University of Ibadan, Nigeria. 
